\title{
Internationalization of Lithuanian SMEs: Investigation of Barriers and Motives
}

\author{
Renata Korsakiene, Vilnius Gediminas Technical University
}

\begin{abstract}
The presented paper aims to reveal internationalization barriers and motives of Lithuanian small and medium size enterprises (SMEs). The perceptions of internationalized and non-internationalized firms were assessed. The present study applied a survey method of data collection. Profit goals and networks are seen as the main drivers of internationalization. However, intense competition abroad was seen as the most significant factor, hindering expansion of firms. The assessment of strengths revealed the difference between internationalized and non-internationalized firms. The availability of advantageous products and services in domestic markets was seen as important factor for internationalization. The findings of the survey led us to elaborate implications and policy measures.
\end{abstract}

Keywords - Barriers, internationalization, Lithuania, motives, SMEs.

\section{INTRODUCTION}

Globalization, technological changes, intense competition, fluctuating demand of consumers, economic and political changes impact managers' decisions to take greater risks and to expand firms' activities overseas. Internationalization of firms is regarded as an important measure of competitive performance at national as well as at regional level [38]. It is widely recognized that internationalization contributes to the growth of revenues of firms due to economies scale and scope, manufacturing efficiencies, access to foreign technological, marketing and management know-how [25].

Small and medium size enterprises (SMEs) play a significant role in any country's economy by contributing to revenue generation and employment. Governments throughout all the European Union strive to encourage SMEs to trade internationally by developing policy measures [40]. The firms are encouraged to trade internationally from the outset and to increase their international expansion. Internationalization of SMEs has attracted considerable attention of researchers in recent years. The phenomenon has been investigated in the strategy, international business and entrepreneurship areas.

A number of studies have investigated the factors and barriers for internationalization [20], [23], [27], [31]. The researchers agree that the expansion of firms to international markets is restricted by a number of attitudinal, structural, operational and other constraints, limiting the ability to initiate, develop and sustain business abroad. Many challenges of internationalization are associated with liability of foreignness and newness [24]. These challenges are seen of higher importance if the target market is dissimilar to the domestic market and if new subsidiaries are established. Hence, firms are fostered to acquire new resources and capabilities when entering a foreign market. Notably, smallness is seen as disadvantage in internationalization, as SMEs often lack resources (especially capital resources) and capabilities that restrict possibility to capture business opportunities. Therefore, resource constraints and resource commitments in the conditions of environmental uncertainty are seen as the main characteristics common to small firms [33].

The presented paper aims to reveal internationalization barriers and motives of Lithuanian SMEs. In particular, it seeks to explore approaches taken by internationalized and non-internationalized firms. The paper is organized as follows: In section 2 literature review on internationalization is discussed; In section 3 different approaches towards the barriers and motives are analyzed; In section 4 the methodology and the results of the survey which was carried out in order to reveal SMEs perceptions about barriers and motives are presented; The final part presents the conclusions.

\section{LITERATURE REVIEW ON INTERNATIONALIZATION}

Various scholars have brought considerable understanding of the SMEs internationalization phenomenon. However, in comparison to internationalization of multinational firms, SMEs internationalization is seen as a relatively new area of research.

Some scholars claim that internationalization means a changing state. Hence, the growth of a firm provides background to internationalization and the concepts of internationalization and growth are interrelated [2]. Meanwhile, some scholars state that "some features are unique to internationalization or, at least, there are significant degrees of difference between growth at home and growth internationally" [32].

Initially, internationalization theories emphasized the process, through which firms were increasingly involved in international markets [16], [37]. The gradualist approach, adopted by several proponents, emphasized sequential steps through which firms become increasingly committed to and involved in international markets.

Notably, the gradualist approach began to be increasingly challenged at the beginning of 1990s [21]. Instead, some scholars emphasized development of "networks of business relationships in other countries through extension, penetration and integration" [17], [15]. Hence, knowledge and international networks have been investigated as main sources of internationalization.

Despite the various views toward the definition of internationalization, the author of this paper adopts the approach that internationalization is the expansion of firm's 
operations to foreign markets and agrees with the notion that internationalization could result from punctual and independent actions. On the other hand, the investigation of the main internationalization approaches and models allow revealing the complexity of the phenomenon.

Notably, internationalization studies are based on several views toward internationalization, namely - stage, learning, contingency and network approaches.

Initially, stage approaches aimed to explain the internationalization process by the mode of entry to international markets. The scholars, supporting this approach, state that firms start with the mode of entry which requires the least commitment of resources and with experience in the market increase their commitment of resources to international activities [3].

The shift of interest toward the learning theory encouraged to adopt a view that internationalization is a dynamic process. The Uppsala model assumes interaction of gradual acquisition of knowledge and the resource commitment to the foreign markets, market commitment and decisions to commit resources [16]. The model has emphasized the relevance of psychic distance in international business decisions. According to Johansson and Vahlne, the psychic distance concept was defined as "the sum of factors preventing the flow of information from and to the market" [16]. Therefore, the firms start their internationalization in nearby markets via an intermediary and then could be followed by some form of production abroad.

Meanwhile, the contingency approach to internationalization assumes that the firm evaluates and responds to any opportunity as it occurs, regardless of whether the market is close in psychic distance terms or whether an advanced mode of entry is required [28].

Network approaches emphasize the role of linkages and relationships in the internationalization process [15], [4]. The scholars assume that internationalization takes place in three ways: through creating relationships with partner in new countries; through rising commitment in already established foreign networks; and through integrating their positions in networks in various countries. Hence, the success of the firm in entering new markets depends on its position in the network and relationships within current market.

In a contemporary research, different approaches toward internationalization are seen as complimentary views where a combination of views is preferred "since it is difficult to investigate internationalization using only one approach" [14]. The stage approach is being increasingly combined with network approach and foreign direct investment theory (including transaction cost analysis) [5], [18]. Meanwhile, other scholars integrate process models, innovation models, network approach, resource-based view and international entrepreneurship theory [32].

\section{BARRIERS AND MOTIVES OF INTERNATIONALIZATION}

The expansion to international markets is restricted by a number of attitudinal, structural, operational and other constraints, limiting the ability to initiate, develop and sustain business abroad. It has been highlighted by several scholars that the barriers to entry are significantly higher for SMEs than for larger firms [13]. The main underlying premise adopted by scholars is that SMEs often lack resources and capabilities that restrict the possibility to capture business opportunities. Meanwhile, Fillis states that these barriers alone "are not enough to act as preventative measures to stop the firm entering and progressing through the various stages of internationalization" [9]. However, the aim to understand these constraints and to propose appropriate political measures has attracted significant consideration of researchers.

Notably, some scholars distinguish exogenous or endogenous barriers to entry [29]. Exogenous barriers are related to the underlying market conditions and firms are not able to control these barriers. Meanwhile, endogenous barriers are created by incumbent firms through their strategies and market behaviour. Notably, external impediments are marketing activities by competitors in overseas markets and perception of higher risk in overseas markets, knowledge of the market and how it operates, cost issues, lack of export training and government assistance [19]. Finally, the most important external incentives are availability of export incentives from government, overseas demand factor, fall in domestic demand or excess capacity and reduction in costs of production [19].

The scholars, aiming to explain different barriers to entry as well as motives, adopt resource-based view (RBV), knowledge based view (KBV) and network theory.

The proponents of RBV assume that: 1) firms are bundles of resources; 2) firms within an industry are heterogeneous in the resources they control; 3) these resources may not be perfectly mobile across firms [30], [1]. Hence, the firm can achieve sustainable competitive advantage both in domestic and overseas markets by acquiring and developing resources that are valuable, unique, non-tradable, rare, non-substitutable or non-imitable [6]. On the contrary, the firm, which does not accumulate such resources is seen as disadvantageous in comparison to other firms and has limited possibilities to expand abroad.

Building upon previous theoretical studies, researchers conclude that resources and capabilities acquired by an entrepreneur have an important impact on the ability to enter foreign markets [38]. Therefore, the assumptions based on RBV have led to a range of factors that encourage some owner-managed firms to export goods and services abroad. For instance, the entrepreneur can provide general human capital in the form of his own experience and education. Further, management know-how, namely, the central resource of the firm contributes to the ability to identify and select the most suitable partners, investors and advisors. The industry knowledge accumulated by the entrepreneur in other work places contributes to the development of relationships with suppliers and customers. Finally, the ability to obtain the necessary financial resources increases the possibilities of the firm to enter new markets. The research carried out by Westhead, Wright and Ucbasaran has confirmed that businesses with older principal founders with more resources, 
denser information and contact networks, and considerable management know-how are significantly more likely to be exporters [38].

According to Gassmann and Keupp, the resources of the "born-global" SMEs are reduced to a single (intangible) one, namely, knowledge [10]. Hence, taking into consideration environmental constrains the traditional RBV could explain partly the phenomenon of internationalization. The limitations of RBV have shifted the attention of scholars to KBV. Scientific works developed by Grant and other researchers assume that resource and capability advantage are likely to derive from superior access to and integration of specialized knowledge [12]. Hence, the main assumptions adopted by proponents of KBV are: 1) knowledge accounts for greater part of value-added and 2) barriers to the transfer of knowledge highlight the strategic significance of knowledge. Mejri and Unemoto suggest that the lack of tangible resources has to be compensated by intangible resource, that is knowledge, or it will be difficult to compete [26]. Hence, the scholars assume that internationalization is the result of market, network, cultural and entrepreneurial knowledge. Market knowledge is seen as critical for the pre-internationalization phase of the firm. Meanwhile, cultural knowledge, network knowledge and entrepreneurial knowledge contribute to the formation of experiential knowledge, which is considered as being critical for further involvement into foreign markets. Therefore, knowledge based perspective let us assume that the lack of market, network, cultural and entrepreneurial knowledge hinder possibilities of the firm to expand overseas.

The network theory assumes that interaction of various actors, activities and resources influences the firm's expansion in a foreign market. On the other hand, it is common to develop networks among firms with the same technological, market and production characteristics. The research carried out in emerging markets conclude that the firms affiliated to the networks could gain a critical source of knowledge for internationalization from current international activities taking place in the networks. Meanwhile, access to such knowledge will facilitate the acquisitions of business and institutional knowledge compatible with the firms' internal resources and competencies [8]. Hence, the notion exists that the major obstacle in internationalization is the liability of outsidership, i.e., is being or not being part of a network [21].

\section{Methodology AND Results}

The above discussion leads to several research questions. The first relates to the barriers and motives impacting internationalization of Lithuanian SMEs. The second relates to the accumulated resources and capabilities, impacting the position in the domestic market.

SMEs form "the backbone" of the EU economy accounting for $99.8 \%$ of non-financial enterprises in 2012 [7]. Notably, similar situation is observed in Lithuania (Table 1). SMEs play a significant role in growth and development of Lithuania's economy. On the other hand, statistical data presented in Table 1 indicate that Lithuanian SMEs tend to be larger than in the EU [34].
Notably, Lithuanian SMEs are most likely to be active in trade, which accounts for $47 \%$ of Lithuanian SMEs, against EU average $30 \%$. However, their contribution to the employment and value added is lower than the EU average. Hence, the assumption is raised that they are mostly active in small scale trade.

TABLE I

SMALL AND MEDIUM-SIZED ENTERPRISES IN LITHUANIA

\begin{tabular}{|l|l|l|l|l|r|r|}
\hline & \multicolumn{3}{|c|}{ Number of enterprises } & \multicolumn{3}{c|}{ Value added } \\
\hline & \multicolumn{2}{|c}{ Lithuania } & EU27 & \multicolumn{2}{c|}{ Lithuania } & EU27 \\
\hline & Number & Share & Share & Bill. EUR & Share & Share \\
\hline Micro & 91838 & $87.6 \%$ & $92.2 \%$ & 1 & $12.1 \%$ & $21.2 \%$ \\
\hline Small & 10742 & $10.2 \%$ & $6.5 \%$ & 2 & $21.9 \%$ & $18.5 \%$ \\
\hline Medium-sized & 2050 & $2 \%$ & $1.1 \%$ & 3 & $29.4 \%$ & $18.4 \%$ \\
\hline SMEs & 104630 & $99.8 \%$ & $99.8 \%$ & 6 & $63.4 \%$ & $58.1 \%$ \\
\hline
\end{tabular}

Meanwhile, Lithuanian SMEs engaged in services represent only $32 \%$ (the EU average $45 \%$ ), but their contribution to value added is higher than in the EU (respectively $41 \%$ and $43 \%$ ). To conclude, these firms are more productive than similar firms in the EU. Finally, the percentage of Lithuanian SMEs engaged in high-tech manufacturing or knowledgeintensive services is much lower than in the EU [34].

The present study applied a survey method of data collection. The data were collected using a questionnaire. The questionnaire contained several parts. Three sections of the questionnaire cover the assessment of motives and barriers for internationalization and accumulated resources and capabilities in the form of questions using the 5-point Likert scale. The last section includes information of company's profile (e.g. internationalization mode, geographical markets etc.). The questionnaire was sent to 200 SMEs in 2013. Firms in the sample were selected randomly. The survey resulted in 77 responses. The number of the completed questionnaires was 45 which is a response rate of $58 \%$ internationalized SMEs and 32 which is a response rate of $42 \%$ noninternationalized firms. Cronbach's alpha coefficient was used to check the reliability of the questionnaire. The calculated Cronbach's alpha was higher (respectively 0.75 for internationalized and 0.611 for non-internationalized firms) than the minimum acceptable amount [11]. Therefore the reliability of the questionnaire dimensions was verified.

The distribution of respondents according to firm's size was as follows: from micro firms (respectively $24 \%$ of internationalized and $53 \%$ non-internationalized firms), small firms (respectively $42 \%$ from internationalized and $34 \%$ from non-internationalized firms) and medium-size firms (respectively $34 \%$ from internationalized and $13 \%$ from noninternationalized firms). Taking into consideration the fact, that all firms had fewer employees than 250 , we can draw the conclusion that firms can be defined as SMEs.

Out of 77 respondents $17 \%$ indicated that they were currently the owners, $39 \%$ - managing directors and $44 \%-$ line managers. Internationalization of SMEs is seen as essential strategic decision of the firm. Hence, managing position of respondents allows considering them as key 
informants. Notably, the same participants were surveyed in other studies [35]. $78 \%$ of respondents in the sample had a university degree (respectively $38 \%$ had a master's and $40 \%-$ a bachelor's degree). The distribution of the surveyed firms according business was as follows: $30 \%$ of all respondents represented manufacturing, $36 \%$ - trade and $50 \%$ - service sector. Notably, some respondents indicated that their firms were involved in more activities that one.

Taking into consideration that the mode of internationalization is an essential strategic decision for gaining appropriate resources and market position, questions, relating to the operational modes, derived from the stage theory were included in the survey instrument. The obtained results proved the prevailing assumption in scientific literature [36], [39] that firms aim to internationalize through export activities $(62 \%$ of internationalized firms) because exporting is the cheapest and quickest way of internationalization. Meanwhile, own investment abroad was selected only by $4 \%$ of respondents.

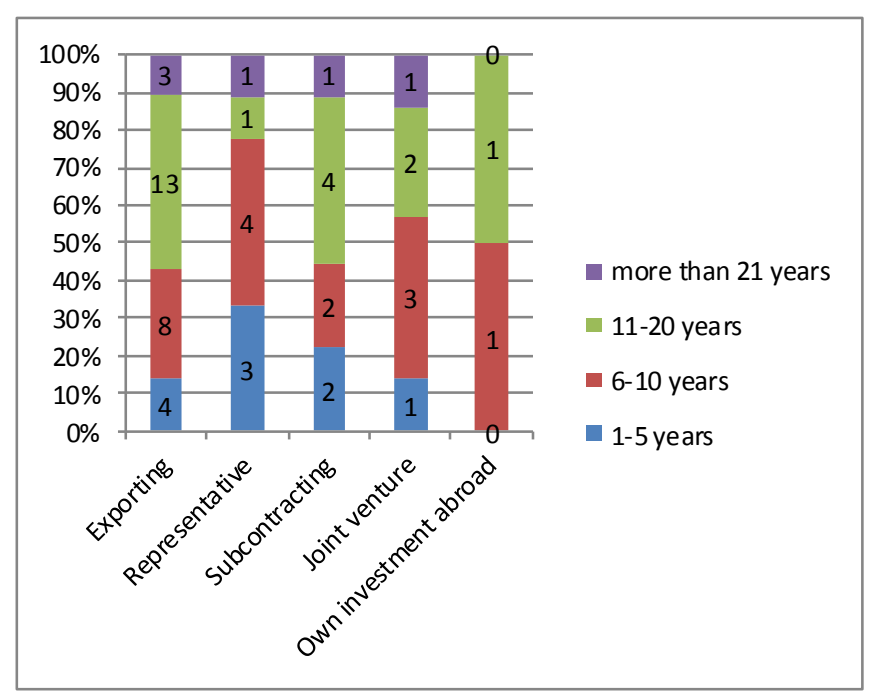

Fig. 1. The mode of internationalization (\%).

The data presented in Fig. 1 allow to conclude that firms operating in the market longer adopt more advanced forms of internationalization. On the other hand, the findings of the research demonstrate that SMEs do not tend to be involved in any (significant) investment and risk and correspond to other findings [33].

Taking into consideration the assumptions of Uppsala model, respondents were asked to indicate the countries of internationalization. The responses of internationalized firms confirm the relevance of psychic distance in international business decisions [16]. To conclude, Lithuanian SMEs internationalize into neighbouring countries, namely Latvia (30\% of respondents), Estonia (21\% of respondents) and Poland (14\% of respondents). Meanwhile the data presented in Fig. 2 allow to conclude that the firms operating in the market longer tend to expand geographical scope.

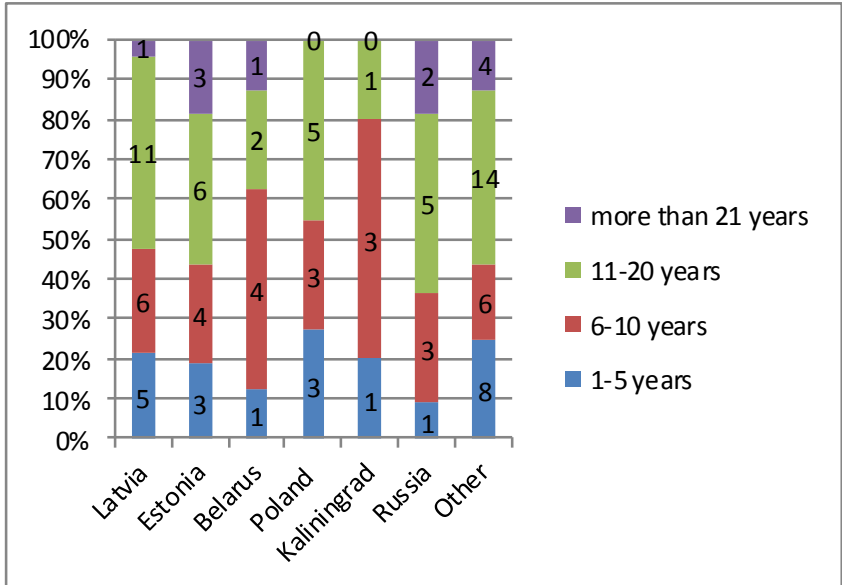

Fig. 2. Countries of internationalization (\%).

Striving to assess the main motives for internationalization, the internationalized firms were asked to evaluate external and internal motives. Taking into consideration assumptions about external motives [19], the respondents were asked to assess: the size of Lithuanian market, competition in domestic market, proximity to customers and suppliers, technological changes in industry, similarity of foreign market and unfavourable laws. Meanwhile, internal motives included profit goals, availability of labour, availability of unique product/technological competence, investment goals, personal relationships and networks abroad and desire to reduce risk. The obtained results are presented in Table II.

TABLE II

EXTERNAL AND INTERNAL MOTIVES OF INTERNATIONALIZED FIRMS

\begin{tabular}{|c|c|c|c|c|}
\hline \multirow{2}{*}{$\begin{array}{l}\text { External and internal } \\
\text { motives }\end{array}$} & \multicolumn{2}{|c|}{ Mean } & \multirow{2}{*}{\begin{tabular}{|c|} 
Std. deviation \\
Statistic \\
\end{tabular}} & \multirow{2}{*}{$\begin{array}{l}\text { Variance } \\
\text { Statistic }\end{array}$} \\
\hline & Statistic & Std. Error & & \\
\hline Small Lithuanian market & 3.8000 & .20986 & 1.40777 & 1.982 \\
\hline $\begin{array}{l}\text { Competition in domestic } \\
\text { market }\end{array}$ & 3.5111 & .20256 & 1.35885 & 1.846 \\
\hline $\begin{array}{l}\text { Proximity to customers } \\
\text { and suppliers }\end{array}$ & 3.,2889 & .21467 & 1.44005 & 2.074 \\
\hline $\begin{array}{l}\text { Technological changes in } \\
\text { industry }\end{array}$ & 2.6000 & .21649 & 1.45227 & 2.109 \\
\hline $\begin{array}{l}\text { Foreign market is similar } \\
\text { to Lithuanian market }\end{array}$ & 2.6000 & .22563 & 1.51357 & 2.291 \\
\hline Unfavourable laws & 2.0889 & .17645 & 1.18364 & 1.401 \\
\hline Profit goals & 4.8000 & .06030 & .40452 & .164 \\
\hline $\begin{array}{l}\text { Availability of skilled } \\
\text { labour }\end{array}$ & 3.6444 & .19373 & 1.29957 & 1.689 \\
\hline $\begin{array}{l}\text { Availability of unique } \\
\text { product/technological } \\
\text { competence }\end{array}$ & 3.6889 & .19022 & 1.27604 & 1.628 \\
\hline Investment goals & 3.4889 & .19752 & 1.32497 & 1.756 \\
\hline $\begin{array}{l}\text { Personal relationships and } \\
\text { networks abroad }\end{array}$ & 3.8222 & .17200 & 1.15383 & 1.331 \\
\hline Desire to reduce risk & 2.9111 & .19803 & 1.32840 & 1.765 \\
\hline
\end{tabular}


To conclude, the most important internal motives impacting internationalization of Lithuanian SMEs are profit goals (mean 4.8, Std. deviation 0.40452) and personal relationships and networks (mean 3.8222, Std. deviation 1.15383). On the other hand, the least important motives are desire to reduce risk (mean 2.9111, Std. deviation 1.32840) and unfavourable laws (mean 2.0889, Std. deviation 1.18364).

When evaluating the external and internal barriers of SMEs internationalization, it was taken into consideration that the SMEs are less competitive in comparison with large firms. The external barriers were perceived as stemming from foreign environment. Hence, such barriers as inaccessible market information, bureaucracy, intense competition abroad, foreign government restrictions and differences in consumer habits were evaluated. Notably, internal barriers included in the survey were as follows: start-up costs, limited financial resources, limited management skills, lack of marketing knowledge, communication issues. The obtained results of the survey are presented in Table III.

TABLE III

BARRIERS OF INTERNATIONALIZATION

\begin{tabular}{|l|l|l|l|l|}
\hline \multicolumn{1}{|c|}{$\begin{array}{c}\text { Barriers of } \\
\text { internationalization }\end{array}$} & \multicolumn{2}{|c|}{$\begin{array}{c}\text { Internationalized } \\
\text { SMEs }\end{array}$} & \multicolumn{2}{c|}{$\begin{array}{c}\text { Non-internationalized } \\
\text { SMEs }\end{array}$} \\
\cline { 2 - 5 } & \multicolumn{1}{|c|}{$\begin{array}{c}\text { Std. } \\
\text { Deviation }\end{array}$} & \multicolumn{1}{c|}{ Mean } & $\begin{array}{c}\text { Std. } \\
\text { Deviation }\end{array}$ \\
\hline $\begin{array}{l}\text { Inaccessible market } \\
\text { information }\end{array}$ & 2.1556 & 1.08619 & 2.7500 & 1.34404 \\
\hline $\begin{array}{l}\text { Bureaucracy (long } \\
\text { administrative procedures, } \\
\text { laws and regulations) }\end{array}$ & 3.0222 & 1.32268 & 3.4063 & 1.21441 \\
\hline $\begin{array}{l}\text { Intense competition } \\
\text { abroad }\end{array}$ & 4.2000 & .94388 & 3.8438 & 1.41671 \\
\hline $\begin{array}{l}\text { Foreign government } \\
\text { restrictions }\end{array}$ & 2.8667 & 1.40777 & 3.0000 & 1.34404 \\
\hline $\begin{array}{l}\text { Differences in consumer } \\
\text { habits and standards }\end{array}$ & 3.4222 & 1.40598 & 3.1875 & 1.40132 \\
\hline Start-up costs & 3.7111 & 1.39190 & 3.7500 & 1.24434 \\
\hline $\begin{array}{l}\text { Limited financial } \\
\text { resources }\end{array}$ & 3.2667 & 1.37179 & 3.8125 & 1.28107 \\
\hline $\begin{array}{l}\text { Limited management } \\
\text { skills }\end{array}$ & 2.5111 & 1.32497 & 2.9688 & 1.44768 \\
\hline $\begin{array}{l}\text { Lack of marketing } \\
\text { knowledge }\end{array}$ & 2.6889 & 1.27604 & 3.0625 & 1.36636 \\
\hline $\begin{array}{l}\text { Communication issues } \\
\text { foreign language) }\end{array}$ & 2.5778 & 1.65816 & 2.5625 & 1.45774 \\
\hline
\end{tabular}

Notably, the responses of internationalized and noninternationalized firms differ significantly. To conclude, the most important barrier for internationalization of the internationalized Lithuanian SMEs is intense competition abroad (respectively, mean 4.2, Std. deviation 0.40452). On the other hand, the least important motive is inaccessible market information (mean 2.1556, Std. deviation 1.086619). This can be explained by the probability that the information barriers decrease as internationalization experience increases [22]. Meanwhile, non-internationalized firms emphasise intense competition abroad. However, the responses of non- internationalized firms are spread out over a large range of values, which represents bigger diversity of answers.

The resources and capabilities accumulated by firms in the domestic market influence competitive position and play a significant role in the internationalization process [40]. Hence, the respondents were asked to assess their strengths in comparison to current competitors. Taking into consideration assumptions of RBV, KBV and network theory respondents were asked to assess marketing efficiency, advertising efficiency, marketing control, information about customers and suppliers, products/services, pricing, relationships with customers, relationships with suppliers, collaboration with other firms, inclination to risk, search for new opportunities. The findings are presented in Table IV.

TABLE IV

STRENGTHS OF FIRMS

\begin{tabular}{|c|c|c|c|c|}
\hline \multirow[t]{2}{*}{ Strengths of firms } & \multicolumn{2}{|c|}{$\begin{array}{c}\text { Internationalized } \\
\text { SMEs }\end{array}$} & \multicolumn{2}{|c|}{$\begin{array}{c}\text { Non-internationalized } \\
\text { SMEs }\end{array}$} \\
\hline & Mean & $\begin{array}{c}\text { Std. } \\
\text { Deviation }\end{array}$ & Mean & $\begin{array}{c}\text { Std. } \\
\text { Deviation }\end{array}$ \\
\hline More efficient marketing & 3.3111 & 1.16428 & 3.4063 & 1.29164 \\
\hline More effective advertising & 2.7778 & 1.39624 & 2.9688 & 1.35562 \\
\hline Marketing control & 3.2667 & 1.30384 & 3.2188 & 1.12836 \\
\hline $\begin{array}{l}\text { Information about } \\
\text { customers and suppliers }\end{array}$ & 4.2889 & .84267 & 3.9688 & .96668 \\
\hline Products/services & 4.5111 & .62603 & 4.313 & .99950 \\
\hline Pricing & 3.9333 & 1.09545 & 3.8750 & 1.09985 \\
\hline $\begin{array}{l}\text { Relationships with } \\
\text { customers }\end{array}$ & 4.1778 & 1.09314 & 4.1250 & .97551 \\
\hline $\begin{array}{l}\text { Relationships with } \\
\text { suppliers }\end{array}$ & 4.2667 & 1.00905 & 3.9063 & 1.20106 \\
\hline $\begin{array}{l}\text { Collaboration with other } \\
\text { firms }\end{array}$ & 3.6667 & 1.16775 & 3.8438 & 1.01947 \\
\hline Inclination to risk & 3.9333 & 1.00905 & 2.9375 & 1.18967 \\
\hline Innovations & 3.9556 & .92823 & 3.5938 & 1.38795 \\
\hline $\begin{array}{l}\text { Search for new } \\
\text { opportunities }\end{array}$ & 4.3778 & .86047 & 4.3125 & .89578 \\
\hline
\end{tabular}

The responses of the respondents led us to reveal that products/services (mean 4.5111, Std. deviation 0.62603), search for new opportunities (mean 4.3778, Std. deviation $0.86047)$ and information about customers and suppliers (mean 4.2889, Std. deviation 0.84267) are the main strengths of internationalized firms. Meanwhile, the responses of noninternationalized firms revealed that search for new opportunities (mean 4.3125, Std. deviation 0.89578), products/services (mean 4.0313, Std. deviation 0.99950) and information about customers and suppliers (mean 3.9688, Std. deviation 0.96668 ) are seen as the main strengths.

\section{CONCLUSION}

The study aimed to gain deeper understanding of perceptions of internationalized and non-internationalized Lithuanian SMEs. The obtained results shed some light on motives to internationalize. Profit goals and networks are seen as main drivers of internationalization. However, intense 
competition abroad is seen as the most significant factor hindering expansion of firms. The assessment of strengths led us to reveal the difference between the internationalized and non-internationalized firms. The availability of advantageous products and services in domestic markets is seen as important factor for internationalization.

Taking into consideration findings of this study different proposals can be elaborated.

First of all, some barriers of internationalization such as intense competition or lack of information can be overcome by forming business networks allowing to acquire limited resources and to benefit from the size of networks. The formation of networks expedites the internationalization efforts of SMEs and improves their success rate. The development of advantageous products or services has to be considered as the priority of entrepreneurs aiming to expand in both national and international markets.

Finally, government support policy should take into consideration the capacity of firms to internationalize. Hence, different support measures should be differentiated by targeting specific clusters of SMEs from trade, service and manufacturing sectors. For instance, additional assistance of government in internationalization process of SMEs, representing knowledge-intensive and high tech industries, should be developed. The information about international networks and possibilities to cooperate with foreign firms has to be provided more intensively. Notably, different support measures should facilitate overcoming of such barriers as limited financial resources and bureaucracy.

The limitations of the presented study are associated with the small sample size. Hence, further research should concentrate on a deeper analysis of differences between business sectors.

\section{REFERENCES}

[1] Barney, J. B, "Firm Resources and Sustained Competitive Advantage," Journal of Management, 1991, vol. 17, pp. 99-120. http://dx.doi.org/10.1177/014920639101700108

[2] Buckley, P. J., Ghauri, P. N., "Introduction and overview," In The internationalization of the firm. London: Academic Press, 1993, pp. ix-xxi.

[3] Cavusgil, T, "On the internationalisation process of firms," European Research 1980, vol. 8, no. 6, pp.273-281.

[4] Chetty, S., Blankenburg-Holm, D., "Internationalization of small an medium-sized manufacturing firms: a network approach," International Business Review, 2000, vol. 9, no. 1, pp. 77-93. http://dx.doi.org/10.1016/S0969-5931(99)00030-X

[5] Coviello, N.E., McAuley, A., "Internationalisation and the smaller firm: a review of contemporary empirical research. Management International Review, 1999, vol. 39, no. 3 pp. 223-256.

[6] D‘Aveni, R. A., Dagnino, G. B., Smith, K. G., "The Age of Temporary Advantage," Strategic Management Journal. 2010, vol. 31, pp. 1371-1385. http://dx.doi.org/10.1002/smj.897

[7] Ecorys. EU SMEs in 2012: at the crossroads. Annual report on small and medium sized enterprises in the EU, 2011/2012. Roterdam, 2012 September.

[8] Ellango, B., Pattnaik, C., "Building capabilities for international operations through networks: a study of Indian firms," Journal of International Business Studies, 2007, vol. 38, pp. 541-555. http://dx.doi.org/10.1057/palgrave.jibs. 8400280

[9] Fillis, I., "Barriers to internationalization: an investigation of the craft microenterprise," European Journal of Marketing, 2002, vol.36 no. 7/8, pp. 912-927. http://dx.doi.org/10.1108/03090560210430872

[10] Gassmann, O., Keupp, M. M., "The competitive advantage of early and rapidly internationalising SMEs in the biotechnology industry: a knowledge based view," Journal of World Business, 2007, vol. 42, no. 3, pp.350-366. http://dx.doi.org/10.1016/j.jwb.2007.04.006

[11] Gliem, J. A.; Gliem, R. R., "Calculating, interpreting, and reporting Cronbach's alpha reliability coefficient for Likert-type scales," Midwest Research-to-Practice Conference in Adult, Continuing, and Community Education, The Ohio State University, Columbus, OH, 2003 October.

[12] Grant, R. M., "Prospering in Dynamically - Competitive Environments: Organizational Capacity as Knowledge Integration,” Organization Science, 1996, vol. 7, pp. 375-387. http://dx.doi.org/10.1287/orsc.7.4.375

[13] Hutchinson, K., Fleck, E., Lloyd-Reason, L. "An investigation into the initial barriers to internationalization: evidence from small UK retailers," Journal of Small Business and Enterprise Development, 2009, vol. 16, no. 4, pp. 544-568. http://dx.doi.org/10.1108/14626000911000910

[14] Jansson, H., Sandberg, S., "Internationalization of small and medium sized enterprises in the Baltic Sea Region," Journal of International Management, 2008, vol. 14, pp.65-77. http://dx.doi.org/10.1016/i.intman.2007.02.005

[15] Johanson, J. and Mattsson, L.G., "Internationalization in industrial systems - a network approach, strategies in global competition," In Buckley, P.J. and Ghauri, P.N. Eds., The Internationalization of the Firm: A Reader, Academic Press, London, 1993, pp. 303-22.

[16] Johanson, J. and Vahlne, J. E., "The internationalization process of the firm - a model of knowledge development and increasing foreign market commitments," Journal of International Business Studies, 1977, vol. 8, no. 1, pp. 23-32. http://dx.doi.org/10.1057/palgrave.jibs.8490676

[17] Johanson, J. and Vahlne, J. E. "The mechanism of internationalization," International Marketing Review, 1990, vol. 7, no. 4, pp. 11-24. http://dx.doi.org/10.1108/02651339010137414

[18] Johanson, J. and Vahlne, J. E. "Business relationship learning and commitment in the internationalization process," Journal of International Entrepreneurship, 2003, vol. 1, pp. 83-101. http://dx.doi.org/10.1023/A:1023219207042

[19] Johnston, W. J. and Czinkota, M. R., "Export attitudes of industrial manufacturers," Industrial Marketing Management, 1985, vol. 14, pp. 123-132. http://dx.doi.org/10.1016/0019-8501(85)90050-1

[20] Katsikeas, C. S. and Piercy, N.F., "Long-term export stimuli and firm characteristics in a Europaen LDC," Journal of International Marketing, 1993, vol. 1, no. 3, pp. 23-47.

[21] Kalinic, I., Forza, C., "Rapid internationalization of traditional SMEs: between gradualist models and born globals," International Business Review, 2012, vol. 21, pp. 694-707. http://dx.doi.org/10.1016/j.ibusrev.2011.08.002

[22] Kneller, R., Pisu, M., "Barriers to exporting: what are they and who do they matter to?" The World Economy, 2011, vol. 34, no. 6, pp. 893-930 http://dx.doi.org/10.1111/j.1467-9701.2011.01357.x

[23] Leonidou, L. C., "Empirical research on export barriers: Review, assessment and synthesis," Journal of International Marketing, 1995, vol. 3, no. 1, pp. 29-43.

[24] Lu, W.J. and Beamish, P. W., "The Internationalization and Performance of SMEs," Strategic Management Journal, 2001, vol. 22, pp. 565-586. http://dx.doi.org/10.1002/smj. 184

[25] Manolova, T. S., Manev, I. M., Gyoshev, B. S., "In good company: the role of personal and inter-firm networks for new-venture internationalization in a transition economy," Journal of World Business 2009 , vol. 45, pp. 257-265. http://dx.doi.org/10.1016/j.jwb.2009.09.004

[26] Mejri, K., Unemoto, K., "Small and medium sized enterprise internationalization: towards the knowledge based model," Journal of International Entrepreneurship, 2010, vol. 8, no. 2, pp. 156-167. http://dx.doi.org/10.1007/s10843-010-0058-6

[27] Morgan, R.E., "Export stimuli and export barriers: Evidence from empirical research studies," European Business Review, 1997, vol. 97, no. 2, pp. 68-79. http://dx.doi.org/10.1108/09555349710162571

[28] Okoroafo, D., "An assessment of critical entry factors affecting modes of entry substitution patterns in foreign product markets," Journal of Global Marketing, 1990, vol. 3, no. 3, pp. 87-104. http://dx.doi.org/10.1300/J042v03n03 06

[29] Pehrsson, A., "Barriers to entry and market strategy: a literature review and a proposed model," European Business Review, 2009, vol. 21, no. 1, pp.64-77. http://dx.doi.org/10.1108/09555340910925184

[30] Penrose, E.T. The theory of the growth of the firm. John Wiley \& Sons: New York, 1959.

[31] Pinho, J. C., Martins, L., "Exporting barriers: insights from Portuguese small- and medium-sized exporters and non-exporters," Journal of International Entrepreneurship, 2010, vol. 8, pp. 254-272. 
http://dx.doi.org/10.1007/s10843-010-0046-x

[32] Ruzzier, M., Hisrich, R.D., Antoncic, B., "SME internationalization research: past, present and future," Journal of Small Business and Enterprise Development, 2006, vol. 13, no. 4, pp. 476-497.

http://dx.doi.org/10.1108/14626000610705705

[33] Ruzzier, M. Konečnik, M., "The internationalization strategies of SMEs: the case of Slovenian hotel industry," Management, 2006, vol. 11, no. 1, pp. 17-35.

[34] SBA Fact Sheet 2012-Lithuania. Available: http://ec.europa.eu/enterprise/ policies/sme/facts-figures-analysis/performance-review/files/countriessheets/2012/lithuania_en.pdf.

[35] Sommer, L., "Internationalization processes of small- and mediumsized enterprises - a matter of attitude?" Journal of International Entrepreneurship, 2010, vol. 8, pp. 288-317.

http://dx.doi.org/10.1007/s10843-010-0052-z

[36] Sousa, C. M. P., Martinez-Lopez, F. J., Coelho, F., "The determinants of export performance: a review of the research in the literature between 1998 and 2005," International Journal of Management Reviews 2008, vol. 10 , no. 4, pp. 343-374.

http://dx.doi.org/10.1111/j.1468-2370.2008.00232.x

[37] Welch, L. S., Luostarinen, R. K., "Internationalization: evolution of a concept," Journal of General Management, 1988, vol. 14, no. 2, pp. 36-64

[38] Westhead, P., Wright, M., Ucbasaran, D., "The internationalization of new and small firms: a resource based view," Journal of Business Venturing, 2001, vol. 16, pp. 333-358. http://dx.doi.org/10.1016/S08839026(99)00063-4

[39] Wheeler, C., Ibeh, K., Dimitratos, P., "UK export performance research: review and implications," International Small Business Journal, 2008, vol. 26, no. 2, pp. 207-239.

http://dx.doi.org/10.1177/0266242607086574

[40] Wright, M., Westhead, P., Ucbasaran, D., "Internationalization of small and medium sized enterprises (SMEs) and international entrepreneurship: a critique and policy implications," Regional Studies, 2007, vol. 41, no. 7, pp. 1013-1029.

http://dx.doi.org/10.1080/00343400601120288
Renata Korsakiene received the Doctor's degree in Management and Administration from Vilnius Gediminas Technical University, Lithuania, in 2001.

She is an Associate Professor with Vilnius Gediminas Technical University, Lithuania. She had taken senior positions in domestic private and public companies. Dr. Korsakiene has been a Visiting Professor at the Universities in the Netherlands, Switzerland, Finland, Spain, Portugal, Latvia and Turkey. She is the author and co-author of a monograph and six books, more than 70 scientific papers, published in scientific journals and conference proceedings indexed and abstracted in numerous international databases. Dr. Korsakiene is a member of editorial boards of eight journals. She has participated in several EU and national projects. Her research interests are: business internationalization, international entrepreneurship, human and social capital, regional development issues.

Adress: Sauletekio Av. 11, LT-10223, Vilnius, Lithuania.

E-mail: renata.korsakiene@vgtu.lt 